Journal of Southeast Asian

\title{
Book Review: Hmong America: Reconstructing Community in Diaspora by Chia Youyee Vang
}

Yang Sao Xiong

University of Wisconsin-Madison, ysxiong2@wisc.edu

\section{Recommended Citation}

Xiong, Yang Sao (2011) "Book Review: Hmong America: Reconstructing Community in Diaspora by Chia Youyee Vang," Journal of Southeast Asian American Education and Advancement. Vol. 6 : Iss. 1, Article 17.

DOI: $10.7771 / 2153-8999.1033$

Available at: https://docs.lib.purdue.edu/jsaaea/vol6/iss1/17

This document has been made available through Purdue e-Pubs, a service of the Purdue University Libraries. Please contact epubs@purdue.edu for additional information.

This is an Open Access journal. This means that it uses a funding model that does not charge readers or their institutions for access. Readers may freely read, download, copy, distribute, print, search, or link to the full texts of articles. This journal is covered under the CC BY-NC-ND license. 


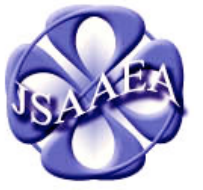

Volume 6 (2011)

\section{Journal of Southeast Asian American}

\section{Education \& Advancement}

WWW.JSAAEA.org
A peer-reviewed scholarly journal published by the National Association for the Education \& Advancement of Cambodian, Laotian, and Vietnamese Americans (NAFEA)

Vang, C. Y. (2010). Hmong America: Reconstructing community in diaspora. Urbana: University of Illinois Press. 192 pp. \$25.00 (Paperback). ISBN: 978-0252-07759-3.

\author{
Reviewed by \\ Yang Sao Xiong \\ University of California, Los Angeles
}

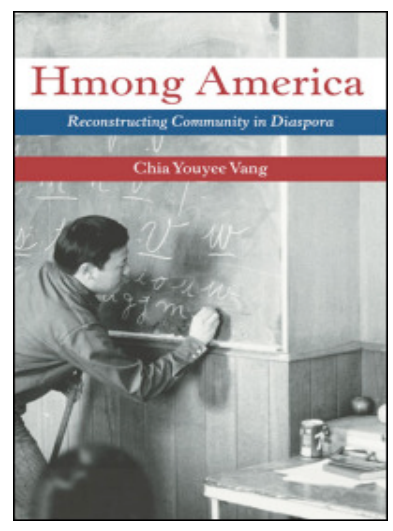

Since the 1980s, an increasing number of researchers have documented Hmong former refugees' cultural and economic adaptation in the United States. Vang's Hmong America provides a recent depiction of Hmong's historical experiences with colonialism and imperialism, their struggles for basic survival during the wars in Laos, their forced displacement, and their attempts to rebuild ethnic communities in Minnesota's Twin Cities. By taking account of Hmong's pre-migration experiences, Hmong America helps clarify the dynamically evolving adaptation of Hmong former refugees and their children, especially their adaptation to new communities, institutions, and governments. By describing Hmong Americans' ongoing trans-state activities, Vang's book also sheds light on the decades-long social, economic and political relationships between Hmong in the U.S. and their Southeast Asian compatriots.

Displaying vigilance and sensitivity to the consequences of group stereotypes, Vang reminds her readers that "the Hmong American community" is neither a monolithic nor homogeneous ethnic community. Rather, Vang points out, immense internal diversity of identities and interests exist in Hmong American communities. This diversity is manifested in the great variety of sub-categories such as dialects, clans, subclans or lineages, voluntary associations, political organizations, ethnic churches, and other categories. From discussing the intra-ethnic divisions created by French colonial co-optation following indigenous revolts in Laos (pp. 20-22) to discussing Hmong Americans' contemporary "politics of representation" (pp. 88-96), each of Vang's chapters invites readers to think about what internal diversity could mean for ethnic members' ability to construct instrumental ethnicity and maintain meaningful cultural traditions.

In my view, it is in Chapters 4 and 5 that Hmong America provides the most lively discussions of Hmong Americans' forms of cultural adaptation and ethnic-political agency. In chapter 4, "Continuity and Reinvention of Traditions," Vang describes the Hmong New Year

\title{
(a)
}

SOMERIGHISRESEREED Readers are free to copy, display, and distribute this article, as long as the work is attributed to the author(s) and the Journal of Southeast Asian American Education \& Advancement, it is distributed for noncommercial purposes only, and no alteration or transformation is made in the work. More details of this Creative Commons license are available at http://creativecommons.org/licenses/by-nc-nd/3.0/. All other uses must be approved by the author(s) or JSAAEA. 
celebration in Minnesota and examines its role in "affirming established Hmong cultural identities and creating new ones" (p. 98). Vang's discussion of Hmong individuals' varied interpretations of the Hmong New Year celebration evokes some of the most interesting, albeit understudied, processes of Hmong's cultural and ideological change.

One such process involves Hmong individuals' anxiety over what they perceive to be the increasing "commercialization" of the traditionally celebrated Hmong New Year event. Arguing that "Hmong Americanization [sic] has come to signify increasing American cultural and economic influence," Vang points out that "many Hmong Americans contend that New Year celebrations have become too commercialized" (p. 105). Ten pages later, Vang briefly revisits this general idea. Vang cites a written passage by an individual who expressed discontent with the new year event because, according to him/her, it has come to contain "strange and odd" programs and be "full [of] business booths ... [that] only [benefit] business folks and the organizers" (p. 116). Vang interprets the writer's discontent to mean that s/he was "argu[ing] against the commodification of New Year celebrations" (p. 116). This interpretation is provocative. However, I wish Vang would have clarified her usage of these Marx-formulated concepts, examined how and in what ways the Hmong New Year has been commodified, and discussed what consequences processes of commodification have had for other social domains of Hmong American life. If by commodification Vang means the transformation of formerly noncommercial relationships into exchange relations, then it would seem important to also address questions such as the following: In the Hmong American context, who or what is doing the commodification, to whom, and under what conditions? And what consequences have commodification of certain practices and their attendant social relationships had, if any, for the maintenance of particular cultural traditions or for the maintenance of ethnic solidarity?

Chapter 5 contains several examples of political activism within Hmong American communities. These examples not only illustrate individual and collective agency, but also help clarify the very important fact that Hmong Americans, despite their relative political invisibility, have never been social isolates. Instead, Hmong Americans frequently engage with people and governments around them and, in doing so, create tangible changes for their communities. Highlighting Hmong Americans' active role in pursuing rights, resources and representation in the U.S. context, Vang points out that especially in recent years, Hmong Americans have engaged in political coalition building and sought political offices at school boards and state legislatures. Furthermore, Vang points out, segments of the Hmong American population continue to participate in contentious "homeland politics," including "long-distance nationalism" (p. 136), which maintains not only the imagined community but also the often ambivalent relationship between Hmong exiles and their former homelands.

Vang contends that through their participation in these forms of U.S. and foreign political activism, "Hmong Americans have been partially responsible for the maintenance of their perpetual refugee identity" (p. 122). To be sure, several factors, including Hmong's involuntary refugee status, make their relationship with the U.S. government a perpetually fluctuating one. That is, Hmong former refugees and their U.S.-born children have, at times, been treated as U.S. allies, but at other times, as aliens ineligible for public benefits, as second class citizens, as perpetually unassimilable foreigners or, even worst, as former terrorists or indicted terrorism plotters. Furthermore, it is often the case that Hmong Americans must construct and evoke a military-service frame during most social movements in order to seek political recognition or resources from state and federal government departments. However, in my view, the claim that 
Hmong Americans are responsible for maintaining an imposed label (i.e., perpetual refugees) demands more substantiation and debate.

Although not "the first scholarly work ... from inside the Hmong community" to examine Hmong's experiences in Laos or their ongoing struggles in America, Vang's book serves as an invaluable introduction to contemporary Hmong American society. One of its strengths is in the breadth of issues in Hmong American communities that it covers. Another is in its careful attention to Hmong's pre-migration experiences, their internal group diversity, and how these complicate and condition the remaking of ethnic communities. Students interested in the processes of refugee adaptation, cultural change and race-ethnic relations in the United States should read Vang's Hmong America.

\section{About the Author}

Yang Sao Xiong is a PhD candidate in the Department of Sociology at UCLA. His research includes the study of the classification, testing and tracking of English learners in public schools and Hmong American students' access to college. His dissertation examines dialect conflict within the Hmong American communities of California and the ways that social actors in that conflict construct social problems and participate in movement framing activities. He graduated from the University of California at Davis, where he received his BA in Asian American studies and sociology.

\footnotetext{
${ }^{1}$ This claim appeared on the back cover of the book under review.
} 


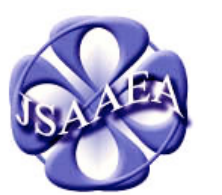

Volume 6 (2011)

\section{Journal of Southeast Asian American Education \& Advancement}

\author{
WWW.JSAAEA.org
}

\section{Editor}

Dr. Wayne E. Wright

University of Texas, San Antonio

\section{Associate Editors}

Dr. Chhany Sak-Humphry

University of Hawaii

Dr. KimOanh Nguyen-Lam

California State University, Long Beach

Book Review Editor

Dr. Vichet Chhuon

University of Minnesota

\section{Creative Works Editor}

Bryan Thao Worra

Lao Assistance Center

Special Advisor

Gregory Green

Curator, Echols Collection on Southeast Asia, Cornell University Library

\section{Journal Manager}

Sovicheth Boun

University of Texas, San Antonio
A peer-reviewed scholarly journal published by the

National Association

for the Education \&

Advancement of

Cambodian, Laotian,

and Vietnamese

Americans (NAFEA)

Comments and questions for the editorial staff may be directed to jsaaea@1ists.sis.utsa.edu

\section{Editorial Review Board}

\author{
Dr. Steve Arounsack \\ California State University, Stanislaus \\ Dr. Phala Chea \\ Lowell Public Schools \\ Dr. Loan Dao \\ Cancer Prevention Institute of California \\ Dr. Sophal Ear \\ U.S. Naval Postgraduate School \\ Dr. Nancy H. Hornberger \\ University of Pennsylvania \\ Dr. Peter Nien-Chu Kiang \\ University of Massachusetts, Boston
}

Dr. Carl L. Bankston III

Tulane University

Dr. George Chigas

University of Massachusetts, Lowell

Dr. Changming Duan

University of Missouri, Kansas City

Dr. Jeremy Hein

University of Wisconsin - Eau Claire

Dr. Samlong Inthaly

Minneapolis Public Schools

Dr. Kevin K. Kumashiro

University of Illinois, Chicago 
Xiong: Book Review: Hmong America: Reconstructing Community in Diaspora

Xiong-Book Review of Hmong America: Reconstructing community in diaspora

\author{
Dr. Jonathan H. X. Lee \\ San Francisco State University \\ Dr. Sue Needham \\ California State University, Dominguez Hills \\ Dr. Max Niedzwiecki \\ Daylight Consulting Group \\ Dr. Clara Park \\ California State University, Northridge \\ Dr. Mark Pfeifer \\ Texas A\&M University, Corpus Christi \\ Dr. Bounlieng Phommasouvanh \\ Minnesota Department of Education \\ Dr. Kalyani Rai \\ University of Wisconsin, Milwaukee \\ Dr. Fay Shin \\ California State University, Long Beach \\ Dr. Cathy J. Schlund-Vials \\ University of Connecticut, Storrs \\ Dr. Yer J. Thao \\ Portland State University \\ Dr. Myluong Tran \\ San Diego State University \\ Dr. Khatharya Um \\ University of California, Berkeley \\ Dr. Linda Trinh Vo \\ University of California, Irvine \\ Dr. Zha Blong Xiong \\ University of Minnesota
}

\author{
Dr. Stacey Lee \\ University of Wisconsin, Madison \\ Dr. Bic Ngo \\ University of Minnesota \\ Dr. Leakhena Nou \\ California State University, Long Beach \\ Dr. Isabelle Thuy Pelaud \\ San Francisco State University \\ Dr. Loan T. Phan \\ University of New Hampshire \\ Dr. Karen Quintiliani \\ California State University, Long Beach \\ Dr. Angela Reyes \\ Hunter College, The City University of New York \\ Dr. Nancy J. Smith-Hefner \\ Boston University \\ Dr. Christine Su \\ Ohio University \\ Dr. Loan Tran \\ University of California, Riverside \\ Dr. Tinou Tran \\ Alief Independent School District \\ Dr. Phitsamay Sychitkokhong Uy \\ University of Massachusetts, Lowell \\ Dr. Terrence G. Wiley \\ Center for Applied Linguistics \\ Dr. Kou Yang \\ California State University, Stanislaus
}

\section{Doctoral Student Editorial Review Board}

\author{
Keo Chea-Young \\ University of Pennsylvania \\ Ketmani Kouanchao \\ California State University, Fullerton \\ Polinda Keo \\ University at Albany \\ Ravy Lao \\ University of California, Santa Barbara \\ Thien-Huong Ninh \\ University of Southern California \\ Malaphone Phommasa \\ University of California, Santa Barbara \\ Rassamichanh Souryasack \\ University of California, Santa Barbara \\ Alisia Tran \\ University of Minnesota \\ Silvy Un \\ University of Minnesota
}

\author{
Annie BichLoan Duong \\ San Joaquin County Office of Education \\ Peter Tan Keo \\ Columbia University \\ Ha Lam \\ Arizona State University \\ Monirith Ly \\ Texas State University-San Marcos \\ Giang Pham \\ University of Minnesota \\ Vanna Som \\ Harvard University \\ Somongkol Teng \\ University of Minnesota \\ Krissyvan Truong \\ Claremount Graduate University \\ Yang Sao Xiong \\ University of California, Los Angeles
}

